\title{
Identifikasi Jumlah Bibit Bandeng Menggunakan Metode K-Means Berbasis HSV Color dan Morfologi
}

\author{
Salman Suleman \\ Staf Pengajar Program Studi Teknik Informatika \\ e-mail: salman@poligon.ac.id
}

\begin{abstract}
Abstrak : Ikan bandeng merupakan salah satu komoditas ketahanan pangan nasional. Ketersediaan bibit bandeng sebagai salah satu pendukung produksi yang utama dalam usaha budidaya bandeng di tambak harus terpenuhi. Faktor ketersediaan benih merupakan hal penting dalam peningkatan komoditas yang berimbas pada peningkatan taraf hidup kesejahteraan petani budidaya bibit bandeng. Bibit ikan bandeng sulit dikenali dikarenakan objeknya berukuran kecil sehingga petani bibit bandeng harus lebih ekstra dalam menghitung jumlah bibit bandeng yang ada dalam satu wadah. Identifikasi bibit bandeng salah satu cara untuk mengetahui informasi jumlah bibit bandeng dalam satu wadah. Identifikasi jumlah bibit bandeng menggunakan metode KMeans berbasis HSV color dan morfologi pada preprocessing. Penelitian ini mengusulkan identifikasi jumlah bibit bandeng menggunakan metode k-means berbasis hsv color dan morfologi, penelitian ini diawali dengan tahapan preprocessing, dilakukan transformasi warna citra RGB ke HSV dan RGB ke Grayscale berdasarkan nilai threshold citra dari S dan V pada ruang warna (color space) HSV dan morfologi, dilanjutkan segmentasi dan ekstraksi fitur berdasarkan area dan proses yang terakhir adalah menghitung jumlah bibit bandeng yang berhasil dikenali sebagai objek bibit bandeng berdasarkan hasil pengklasteran dengan Metode Clustering K-Means. Berdasarkan hasil pengujian, identifikasi bibit bandeng dengan proses preprocessing melakukan konversi warna RGB ke HSV dan Operasi Morfologi terhadap Citra Uji menunjukkan hasil dengan tingkat akurasi mencapai $9.70 \%$ dan error $7.30 \%$.
\end{abstract}

Kata Kunci: bibit bandeng; hsv color; morfologi, k-means;

\section{PENDAHULUAN}

1.1. Latar Belakang

Bandeng merupakan salah satu komoditas ketahanan pangan nasional. Ketersediaan bibit bandeng sebagai salah satu pendukung utama produksi dalam budidaya bandeng di tambak harus terpenuhi. ketersediaan bibit bandeng merupakan salah satu faktor penting dalam meningkatkan jumlah produksi untuk memenuhi permintaan pasar. Transaksi jual beli sering terjadi perbedaan jumlah penghitungan yang didapatkan oleh penjual bibit bandeng dengan jumlah yang diberikan kepada pembeli. Hal ini disebabkan oleh bibit bandeng sulit dikenali disebabkan oleh ukuran kecil sehingga proses penghitungan membutuhkan waktu lebih dalam menghitung jumlah bibit bandeng yang ada dalam satu wadah. Proses perhitungan jumlah bibit bandeng dilakukan dengan cara manual yaitu dengan memindahkan bibit bandeng dari wadah yang belum dihitung ke wadah bibit bandeng yang akan dihitung sehingga butuh waktu yang lama untuk proses perhitungannya.

\subsection{Rumusan Masalah}

Identifikasi bibit bandeng dilakukan untuk memetakan objek pada citra berdasarkan fitur dari masing-masing objek sehingga dapat dilakukan identifikasi untuk mendapatkan jumlah bibit bandeng. Sehingga didapatkan rumusan masalah adalah bagaimana menerapkan model HSV color, Morfologi dan K-Means untuk meningkatkan akurasi perhitungan jumlah bibit bandeng.

\subsection{Tujuan Penelitian}

Tujuan dalam penelitian ini adalah dengan menerapkan model HSV Color, Morfologi dan K-Means diharapkan dapat meningkatkan akurasi perhitungan jumlah bibit bandeng.

\section{PEMBAHASAN}

\subsection{Model Penelitian}

Dari rumusan pada diatas, maka model penelitian dapat digambarkan sebagai berikut :

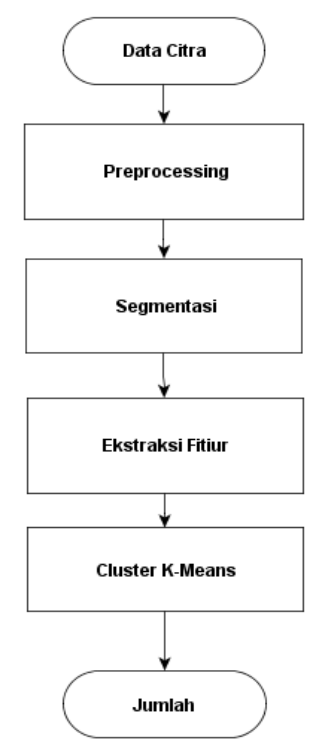

Gambar 1. Model Penelitian

\subsubsection{Citra bibit bandeng}

Citra asli bibit bandeng adalah citra hasil pengambilan gambar dengan kamera 


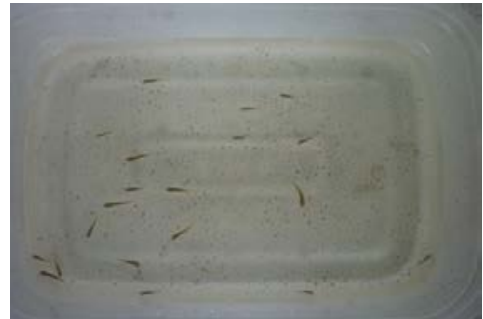

Gambar 2. Citra Asli

Pada penelitian ini menggunakan 30 citra dengan rincian sebagai berikut :

a. 10 citra dengan jumlah bibit bandeng 20

b. 10 citra dengan jumlah bibit bandeng 30

c. 10 citra dengan jumlah bibit bandeng 40

Semua citra yang tidak gunakan masih dalam bentuk asli rgb dalam format .jpg

\subsubsection{Preprocessing}

Pada tahapan ini dilakukan transformasi warna dari RGB ke HSV untuk mendapatkan nilai citra 'S' dan nilai 'V' dan RGB ke Grayscale, hasil dari kedua transformasi warna dilakukan operasi morfologi untuk menghilangkan noise. Untuk konversi warna RGB ke HSV menggunakan persamaan berikut :

$$
\begin{aligned}
& H=\tan \left[\frac{3(G-B)}{(R-G)+(R-B)}\right] \\
& S=1-\frac{\min (R, G, B)}{V} \\
& V=\frac{R+G+B}{3}
\end{aligned}
$$

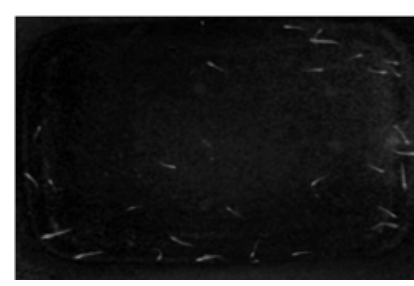

(a) Citra S dari HSV

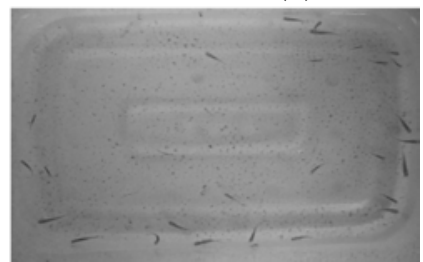

(b) Citra V dari HSV
Gambar 3. Citra HSV dengan nilai S dan V

Operasi morfologi yang dilakukan yaitu opeasi dilasi dan erosi yang sebelumnya dilakukan invert image pada citra ' $S$ ' dan ' $\mathrm{V}$ ' menggunakan fungsi yang ada pada aplikasi MATLAB yaitu imsubstrack dan imcomplement.

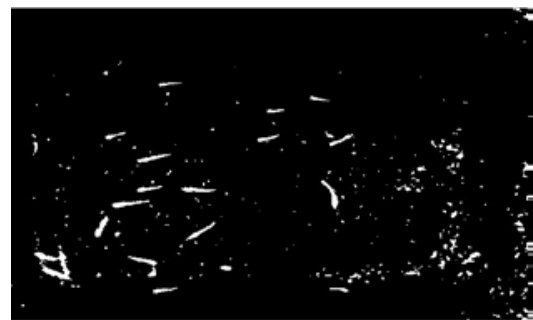

Gambar 4. Citra Hasil Preprocessing

\subsubsection{Segmentasi}

Segmentasi dilakukan pada area (region properties) berdasarkan nilai treshold dari citra S-V pada ruang warna HSV dan grayscale kemudian diidentifikasi dengan Blob Analysis. Blob itu sendiri merupakan kumpulan piksel, untuk mengetahui apakah dua piksel terhubung atau tidak didefinisikan oleh connectivity. Dalam percobaan ini digunakan 8 connectivity karena tingkat akurasi lebih tinggi. Jika didapatkan piksel yang terhubung memiliki nilai piksel yang sama atau yang mendekati yang didefinisikan oleh connectivity maka diberikan label, begitu juga untuk seterusnya. Pelabelan ini berfungsi agar dapat diidentifikasi jumlah objek yang ada pada citra biner.

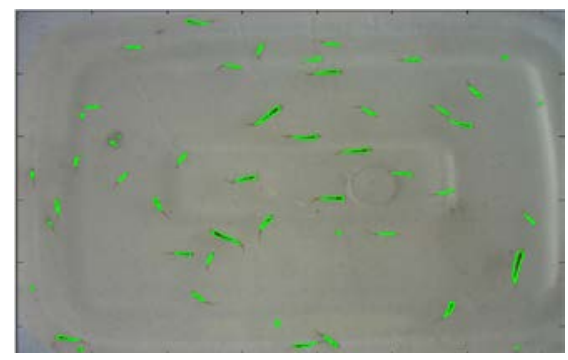

Gambar 5. Hasil Segmentasi Blob

2.1.4. Ekstraksi Fitur

Pada proses ini dengan menggunakan metode region properties (regionprops) untuk memberikan nilai pada wilayah yang terdeteksi pada langkah sebelumnya.

Tabel 1. Hasil Extraksi Fitur

\begin{tabular}{|c|c|c|c|c|}
\hline Objek & Area & Centroid & Bounding Box & Extrema \\
\hline 1 & 8 & {$[1.62500000000000,728.250000000000]$} & {$[0.500000000000000,726.500000000000,3,4]$} & $8 \times 2$ double \\
\hline 2 & 30 & {$[25.2333333333333,781.8333333333333]$} & {$[21.5000000000000,778.500000000000,7,6]$} & $8 \times 2$ double \\
\hline 3 & 38 & {$[47.8157894736842,334.500000000000]$} & {$[44.5000000000000,329.500000000000,7,11]$} & $8 \times 2$ double \\
\hline 4 & 10 & {$[46.7000000000000,384.300000000000]$} & {$[44.5000000000000,382.500000000000,4,4]$} & $8 \times 2$ double \\
\hline 5 & 14 & {$[48.7857142857143,498.785714285714]$} & {$[46.5000000000000,496.500000000000,5,5]$} & $8 \times 2$ double \\
\hline 6 & 167 & {$[51.8502994011976,363.449101796407]$} & {$[46.5000000000000,349.500000000000,10,31]$} & $8 \times 2$ double \\
\hline 7 & 2112 & {$[92.3806818181818,675.537878787879]$} & {$[48.50000000000000,635.5000000000000,80,81]$} & $8 \times 2$ double \\
\hline 8 & 11 & {$[51,590]$} & {$[9.5000000000000,587.5000000000000,3,5]$} & $8 \times 2$ double \\
\hline 9 & 5 & {$[53,632]$} & {$[51.5000000000000,630.500000000000,3,3]$} & $8 \times 2$ double \\
\hline 10 & 10 & {$[54.3000000000000,253.700000000000]$} & {$[52.5000000000000,251.500000000000,4,4]$} & $8 \times 2$ double \\
\hline 11 & 20 & {$[56.3000000000000,609.800000000000]$} & {$[54.5000000000000,605.500000000000,4,9]$} & $8 \times 2$ double \\
\hline 12 & 8 & {$[56.5000000000000,620.500000000000]$} & {$[54.5000000000000,618.500000000000,4,4]$} & $8 \times 2$ double \\
\hline 13 & 8 & {$[63.5000000000000,706]$} & {$[61.5000000000000,704.500000000000,4,3]$} & $8 \times 2$ double \\
\hline 14 & 17 & {$[67.1176470588235,676.529411764706]$} & {$[64.5000000000000,673.500000000000,5,6]$} & $8 \times 2$ double \\
\hline 15 & 25 & {$[78.6800000000000,345]$} & {$[75.5000000000000,342.500000000000,6,6]$} & $8 \times 2$ double \\
\hline 16 & 14 & {$[89.5000000000000,174.714285714286]$} & {$[86.5000000000000,172.500000000000,6,4]$} & $8 \times 2$ double \\
\hline 17 & 13 & {$[92.9230769230769,594.923076923077]$} & {$[90.5000000000000,592.500000000000,5,5]$} & $8 \times 2$ double \\
\hline 18 & 15 & {$[95.4666666666667,498.866666666667]$} & {$[92.5000000000000,496.500000000000,6,5]$} & $8 \times 2$ double \\
\hline 19 & 27 & {$[97.8148148148148,477.814814814815]$} & {$[94.5000000000000,474.500000000000,6,6]$} & $8 \times 2$ double \\
\hline 20 & 35 & {$[102.828571428571,628.028571428572]$} & {$[99.5000000000000,623.500000000000,7,9]$} & $8 \times 2$ double \\
\hline
\end{tabular}

\section{a. Area}

Menentukan jumlah total piksel yang bernilai 1 (true) pada citra biner.

\section{b. Centroid}

Menentukan titik tengah pada setiap obyek, titik tengah didapat dengan menentukan terlebih dahulu matrik setiap obyek. Titik tengah pada sebuah objek yang dihasilkan oleh regionprops Setiap objek memiliki centroid dengan koordinat titik $\mathrm{x}$ dan $\mathrm{y}$. titik inilah yang menjadi sumber data untuk mengetahui masing-masing objek. 


\section{c. Bounding Box}

Setiap baris dari matrik berisi titik koordinat $\mathrm{x}$ dan y dari salah satu poin. Matrik pada setiap obyek memiliki batasan-batasan, yakni batas atas-kiri, atas-kanan, bawahkiri, dan bawah-kanan. Dari batasan-batasan tersebut, akan didapat titik tengah dari setiap obyek yang ada pada citra.

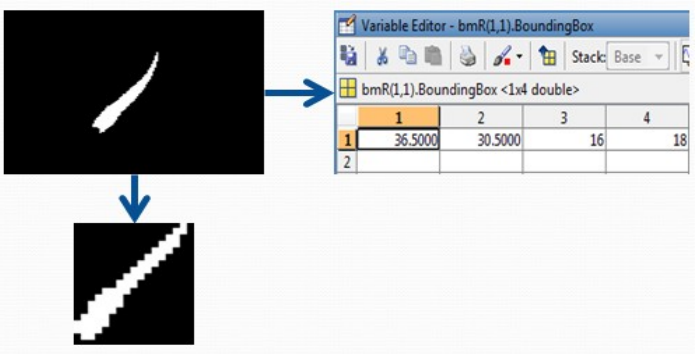

Gambar 6. Hasil boundingbox

\section{d. Extrema}

Pada delapan titik yang melingkari masing-masing objek, yang diperoleh dari fungsi regionprops. Delapan koordinat inilah yang menjadi sumber data untuk mengetahui bentuk luar dari sebuah objek. Untuk mendapatkan objek dilakukan menggunakan rumus euclodian disctance

$$
\sqrt{\left(X_{1}-X_{2}\right)^{2}+\left(Y_{1}-Y_{2}\right)^{2}}
$$

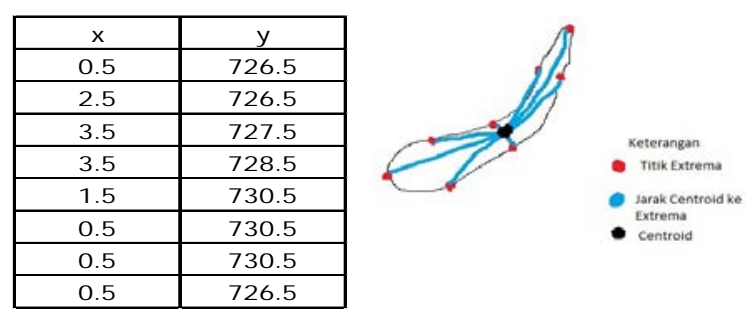

Gambar 6. Pengenalan pola 8 titik ekstrema

\subsubsection{Cluster K-Means}

Pada penelitan ini pengklasteran citra menggunakan algortima K-Means. Fungsi algoritma ini adalah untuk membagi sekumpulan objek menjadi beberapa kelompok berdasarkan kriteria yang ada dengan melihat centroid yang diberikan. Pengelompokkan dapat dilihat dari jarak objek dengan titik tengah yang terdekat. Setelah mengetahui centroid terdekat, objek yang ditemukan akan diidentifikasi sebagai anggota dari kriteria tersebut. Berikut Tahapan pada algoritma k-means yang digambarkan dalam bentuk diagram alir (flowchart)

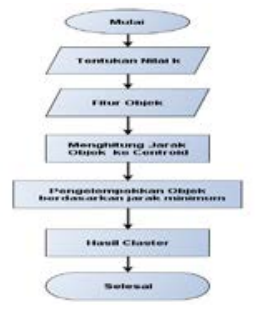

Gambar 5. Alur K-Means

\subsubsection{Pengenalan pola}

Pengenalan pola adalah langkah untuk mengetahui bentuk dari objek. Objek yang dikenali adalah semua objek yang diperoleh pada proses ekstraksi fitur. Objek dalam penelitian terdiri dari dua yaitu :

- Objek bibit bandeng

Objek bibit bandeng adalah citra objek yang dikenali sebagai bibit bandeng dan dibuktikan dengan bentuk citra asli.

- Objek bukan bibit bandeng

Objek bukan bibit bandeng adalah objek yang dideteksi sebagai gangguan yang berada pada wadah yang sama.

Objek ini dikenali dengan memanfaatkan empat dari bagian dari region propertis yaitu area, centroid, extrema dan bounding box.

\subsubsection{Pengelompokan}

Dari banyak pola diambil 12 data pola sebagai contoh untuk penerapan algoritma k-means dalam pengelompokan bibit bandeng. Percobaan dilakukan dengan menggunakan parameter-parameter berikut :

Jumlah cluster : 2

Jumlah objek : 12

Jumlah fitur $\quad: 8$

Tabel 2. Data Pola K-Means

\begin{tabular}{|c|c|r|r|r|r|r|r|r|}
\hline Data & Fitur 1 & \multicolumn{1}{c|}{ Fitur 2 } & \multicolumn{1}{|c|}{ Fitur 3 } & Fitur 4 & Fitur 5 & Fitur 6 & \multicolumn{1}{c|}{ Fitur 7 } & Fitur 8 \\
\hline Objek 1 & 1.802776 & 1.802776 & 2.06155 & 2.06155 & 1.80278 & 1.80278 & 2.061553 & 2.061553 \\
\hline Objek 2 & 1.581139 & 1.581139 & 1.58114 & 1.58114 & 1.58114 & 1.58114 & 1.581139 & 1.581139 \\
\hline Objek 3 & 28.47487 & 42.17165 & 50.403 & 50.1187 & 15.9209 & 31.1342 & 61.90624 & 61.88817 \\
\hline Objek 4 & 78.06952 & 77.17939 & 62.8646 & 63.7061 & 49.7824 & 48.5456 & 85.55583 & 85.92755 \\
\hline Objek 5 & 2.915476 & 2.54951 & 2.54951 & 2.91548 & 2.91548 & 2.54951 & 2.54951 & 2.915476 \\
\hline Objek 6 & 105.536 & 104.6821 & 79.6479 & 80.1061 & 66.8297 & 65.9827 & 107.9063 & 108.8604 \\
\hline Objek 7 & 83.33657 & 80.98471 & 66.4959 & 67.7344 & 64.7654 & 64.1262 & 79.17744 & 82.99673 \\
\hline Objek 8 & 1.581139 & 1.581139 & 1.58114 & 1.58114 & 1.58114 & 1.58114 & 1.581139 & 1.581139 \\
\hline Objek 9 & 5.195475 & 5.022972 & 6.6925 & 6.91177 & 6.10444 & 4.30724 & 5.381363 & 6.165218 \\
\hline Objek 10 16.49837 & 17.08841 & 17.0632 & 16.4635 & 12.4615 & 13.2672 & 15.5749 & 14.66278 \\
\hline Objek 11 & 2.392309 & 1.929544 & 2.50372 & 2.74615 & 2.61037 & 2.19409 & 2.503716 & 2.64497 \\
\hline Objek 12 & 11.14136 & 11.45056 & 9.83558 & 9.28842 & 12.3306 & 12.7694 & 12.43124 & 8.204774 \\
\hline
\end{tabular}

Langkah-langkah pengelompokkan k-means

\section{Iterasi ke-1}

\section{- Penentuan pusat awal cluster}

Untuk penentuan awal diasumsikan dengan mengambil nilai objek ke-2 sebagai pusat Cluster ke-1: (1.58113883,1.58113883, 1.58113883, 1.5811388, 31.58113883, 1.58113883, 1.58113883, 1.58113883) Mengambil nilai objek ke-3 sebagai pusat Cluster ke2:(28.47487038, 42.1716472, 50.4030271, 50.118741, 15.9209444, 31.1342132, 61.9062399, 61.8881682)

\section{- Perhitungan jarak pusat cluster}

Untuk mengukur jarak antara data dengan pusat cluster digunakan Euclidian distance, kemudian akan didapatkan matrik jarak yaitu C1 dan C2 sebagai menggunakan Rumus Euclidian distance 


$$
\mathrm{d}(\mathrm{x}, \mathrm{y})=|x-y|=\sqrt{\sum_{i=1}^{n}\left(x_{i}-y_{i}\right)^{2}}
$$
berikut :

Dari rumus diatas didapatkan perhitungan sebagai

$$
\begin{aligned}
& \mathrm{C} 1= 1.0582 \\
& \mathrm{C} 2= \sqrt{ }(1.802776-28.474870 \\
&42.1716472)^{\wedge} 2+(2.061 \\
&50.118741)^{\wedge} 2+(1.80 \\
&31.1342132)^{\wedge} 2+(2.061 \\
& \mathrm{C} 2= 123.32 \\
& \mathrm{D}(\mathrm{C} 1, \mathrm{C} 2)= {[\mathrm{C} 1-\mathrm{C} 2] } \\
& \mathrm{D}(\mathrm{C} 1, \mathrm{C} 2)=[1.0583-123.32] \\
& \mathrm{D}(\mathrm{C} 1-\mathrm{C} 2)=1.05815
\end{aligned}
$$$$
\text { C1 }=\sqrt{ }(1.802776-1.58113883)^{\wedge} 2+(1.802776-
$$$$
1.58113883)^{\wedge} 2+(2.06155-1.58113883)^{\wedge} 2+(1.80278-
$$$$
1.58113883)^{\wedge} 2+(1.80278-1.58113883)^{\wedge} 2+(2.061553-
$$$$
\left.1.58113883)^{\wedge} 2+(2.061553-1.58113883) \wedge 2\right)
$$$$
\mathrm{C} 2=\sqrt{ }(1.802776-28.47487038)^{\wedge} 2+(1.802776-
$$

\begin{tabular}{|c|c|c|c|c|c|c|c|c|c|c|c|}
\hline Data & Fitur 1 & Fitur 2 & Fitur 3 & Fitur 4 & Fitur 5 & Fitur 6 & Fitur 7 & Fitur 8 & $\mathrm{C} 1$ & $\mathrm{C}_{2}$ & Jarak Terpendek \\
\hline bbjek1 & 1.802776 & 1.802776 & 2.06155 & 2.06155 & 1.80278 & 1.80278 & 2.061553 & 2.061553 & 1.0582 & 123.32 & 1.058150215 \\
\hline bjek2 & 1.581139 & 1.581139 & \begin{tabular}{|l|l|} 
& 1.58114 \\
\end{tabular} & 1.58114 & 1.58114 & 1.58114 & 1.581139 & 1.581139 & n & 124.36 & 0 \\
\hline jek 3 & 28.47487 & 42.17165 & 50.403 & 50.1187 & 15.9209 & 31.1342 & 61.90624 & 61.88817 & 124.36 & & 0 \\
\hline ek 4 & 78.06952 & 77.17939 & 62.864 & 63.7061 & 49.7824 & 48.5456 & 85.55583 & 85.92755 & 194.62 & 81.3144 & 81.31439569 \\
\hline bjek5 & 2.915476 & 2.54951 & \begin{tabular}{|l|}
2.54951 \\
\end{tabular} & 2.91548 & 2.91548 & 2.54951 & 2.54951 & 2.915476 & 3.2974 & 121.361 & 3.297391572 \\
\hline bjek 6 & 105.536 & 104.6821 & \begin{tabular}{|l|}
79.6479 \\
\end{tabular} & 80.1061 & 66.8297 & 65.9827 & 107.9063 & 108.8604 & 254.79 & 140.46 & 140.4599639 \\
\hline bjek 7 & 83.33657 & 80.98471 & 66.495 & 67.7344 & 64.7654 & 64.1262 & 79.17744 & 82.99673 & 205.26 & 96.4555 & 96.45553723 \\
\hline jek 8 & 1.581139 & 1.581139 & \begin{tabular}{|l|l|}
1.58114 \\
\end{tabular} & 1.58114 & \begin{tabular}{|l|l|}
1.58114 \\
\end{tabular} & 1.58114 & 1.581139 & 1.581139 & & 124.36 & 0 \\
\hline jek 9 & 5.195475 & 5.022972 & 6.6925 & 6.91177 & 6.10444 & 4.30724 & 5.381363 & 6.165218 & 11.95 & 113.206 & 11.94983911 \\
\hline $\begin{array}{lll}10 \\
\end{array}$ & 16.49837 & 17.08841 & 17.063 & 16.4635 & 12.4615 & 13.2672 & 15.5749 & \begin{tabular}{|l|}
14.66278 \\
\end{tabular} & 39.32 & 87.8911 & 39.32022488 \\
\hline bjek 11 & 2.392309 & 1.929544 & \begin{tabular}{|l|}
2.50372 \\
\end{tabular} & 2.74615 & 2.61037 & 2.19409 & 2.503716 & 2.64497 & 2.5309 & 122.03 & 2.530948449 \\
\hline bjek 12 & 11.14136 & 11.45056 & \begin{tabular}{|l|l|}
9.83558 \\
\end{tabular} & 9.28842 & 12.3306 & 12.7694 & 2.43124 & 8.204774 & 26.808 & 101.178 & 26.80794626 \\
\hline
\end{tabular}$$
42.1716472)^{\wedge} 2+(2.06155-50.4030271)^{\wedge} 2+(1.80278-
$$$$
50.118741)^{\wedge} 2+(1.80278-15.9209444)^{\wedge} 2+(2.061553-
$$$$
\left.31.1342132)^{\wedge} 2+(2.061553-61.9062399)^{\wedge} 2\right)
$$

Jadi jarak terpendek dari C1 dan C2 adalah 1.05815

Tabel 3. Hasil perhitungan jarak terpendek

\section{- Pengelompokan data}

Setelah didapatkan Jarak dari hasil perhitungan akan dilakukan perbandingan dan akan dipilih jarak minimal antara data dengan pusat cluster, jarak ini dapat menunjukkan bahwa data tersebut berada dalam satu kelompok bersama pusat cluster terdekat. Berikut ini adalah data matriks pengelompokkan group, nilai 1 berarti data tersebut berada dalam group.

Tabel 5. Hasil Pengelompokan pada iterasi ke -1

G1
\begin{tabular}{|c|c|c|}
\hline No & C1 & C 2 \\
\hline 1 & 1 & 0 \\
\hline 2 & 1 & 0 \\
\hline 3 & 0 & 1 \\
\hline 4 & 0 & 1 \\
\hline 5 & 1 & 0 \\
\hline 6 & 0 & 1 \\
\hline 7 & 0 & 1 \\
\hline
\end{tabular}

\begin{tabular}{|c|c|c|}
8 & 1 & 0 \\
\hline 9 & 1 & 0 \\
\hline 10 & 1 & 0 \\
\hline 11 & 1 & 0 \\
\hline 12 & 1 & 0 \\
\hline
\end{tabular}

\section{- Penentuan pusat cluster baru}

\begin{tabular}{|c|c|c|c|c|c|c|c|c|c|c|}
\hline Data & & 12 & 13 & 44 & ur 5 & ur 6 & 17 & 88 & & \\
\hline objek & 0278 & 2278 & 2.06155 & 6155 & 027 & 1.80278 & 06155 & 661 & 3885 & 73.8 \\
\hline bjek 2 & 8114 & 8114 & 1.58114 & 8114 & 8114 & 1.58114 & 581144 & 881 & $3 / 5 /$ & \\
\hline jek3 & 47487 & 17165 & 50.40303 & 50.11874 & 2094 & 31.13421 & 61.90624 & 1.8881 & 1835 & \\
\hline bjek 4 & .06952 & 77.17939 & 62.86461 & \begin{tabular}{|l|l}
63.70612 \\
\end{tabular} & 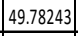 & 48.54560 & 85.55583 & 85.92755 & 5.4436 & 65.41 \\
\hline Objekk & .91548 & 2.54951 & 2.54951 & \begin{tabular}{|l}
2.91548 \\
\end{tabular} & 2.91548 & 2.54951 & 2.54951 & 2.91548 & $5.1 / 3$ & 49.32 \\
\hline Objek 6 & .53601 & 104.68210 & 79.64791 & 30.10610 & 6.82974 & 5.98273 & 107.90634 & 108.86037 & 5.0065 & 52.44 \\
\hline Objekk & 33657 ] & 8471 & 66.49586 & 67.73435 & 64.76542 & 64.12624 & 79.17744 & 99673 & 35.548 & 83.636 \\
\hline Objek & 4] & 8114 & 1.58114 & 1.58114 & 1.58114 & 1.58114 & 1.58114 & 58114 & 4.977 & 84.918 \\
\hline bjek 9 & 5.19548 & 5.02297 & 6.69250 & \begin{tabular}{|l}
6.91177 \\
\end{tabular} & 6.10444 & 4.30724 & 5.38136 & 6.16522 & & \\
\hline$k 10$ & 16.49837 & 17.08841 & 17.06318 & 16.46350 & 2.46154 & 13.26723 & 15.57490 & 14.66278 & & \\
\hline & 2.392311 & 9564 & & & & 2.19 & 2.503 & 2.64 & & \\
\hline & & & & & & & & & & \\
\hline
\end{tabular}

Setelah diketahui nilai anggota dari tiap-tiap cluster, kemudian pusat cluster baru akan dihitung berdasarkan nilai anggota tiap-tiap cluster sesuai dengan rumus pusat anggota cluster. Sehingga didapatkan hasil perhitungan sebagai berikut :

Tabel 6. Pusat Cluster baru

\section{Iterasi Ke-2}

Untuk pencarian nilai baru dilakukan dengan cara mengulangi langkah ke 2 (kedua) hingga posisi data tidak lagi mengalami perubahan nilai.

$$
\begin{aligned}
\text { Cluster baru ke-1 : } & (5.38850517,5.37575694,5.48353893, \\
& 5.44364459,5.17343162,5.00656462, \\
& 5.45806919,4.977131637)
\end{aligned}
$$

Cluster baru ke-2: (73.8542417, 76.2544617, 64.8528496, 65.416328, 49.3246322, 52.4471962, 83.63646116, 84.91820533)

Tabel 7. Hasil perhitungan jarak terdekat pada Iterasi ke-2

\begin{tabular}{|c|c|r|r|r|r|r|r|r|r|r|c|}
\hline Data & Fitur 1 & \multicolumn{1}{|c|}{ Fitur 2 } & \multicolumn{1}{c|}{ Fitur 3 } & Fitur 4 & Fitur 5 & Fitur 6 & Fitur 7 & Fitur 8 & \multicolumn{1}{c|}{ C1 } & C2 & $\begin{array}{c}\text { Jarak } \\
\text { Terpendek }\end{array}$ \\
\hline Objek 1 & 1.802776 & 1.802776 & 2.06155 & 2.06155 & 1.80278 & 1.80278 & 2.061553 & 2.061553 & 9.5097 & 192.442 & 9.509716 \\
\hline Objek 2 & 1.581139 & 1.581139 & 1.58114 & 1.58114 & 1.58114 & 1.58114 & 1.581139 & 1.581139 & 10.5 & 193.449 & 10.499729 \\
\hline Objek 3 & 28.47487 & 42.17165 & 50.403 & 50.1187 & 15.9209 & 31.1342 & 61.90624 & 61.88817 & 114.56 & 78.9707 & 78.970715 \\
\hline Objek 4 & 78.06952 & 77.17939 & 62.8646 & 63.7061 & 49.7824 & 48.5456 & 85.55583 & 85.92755 & 184.34 & 6.7555 & 6.755498 \\
\hline Objek 5 & 2.915476 & 2.54951 & 2.54951 & 2.91548 & 2.91548 & 2.54951 & 2.54951 & 2.915476 & 7.2766 & 190.252 & 7.276629 \\
\hline Objek 6 & 105.536 & 104.6821 & 79.6479 & 80.1061 & 66.8297 & 65.9827 & 107.9063 & 108.8604 & 244.49 & 62.4375 & 62.437502 \\
\hline Objek 7 & 83.33657 & 80.98471 & 66.4959 & 67.7344 & 64.7654 & 64.1262 & 79.17744 & 82.99673 & 194.84 & 22.7762 & 22.776201 \\
\hline Objek 8 & 1.581139 & 1.581139 & 1.58114 & 1.58114 & 1.58114 & 1.58114 & 1.581139 & 1.581139 & 10.5 & 193.449 & 10.499729 \\
\hline Objek 9 & 5.195475 & 5.022972 & 6.6925 & 6.91177 & 6.10444 & 4.30724 & 5.381363 & 6.165218 & 2.5597 & 181.947 & 2.559683 \\
\hline Objjk 10 & 16.49837 & 17.08841 & 17.0632 & 16.4635 & 12.4615 & 13.2672 & 15.5749 & 14.66278 & 28.873 & 154.702 & 28.873133 \\
\hline Objek 11 & 2.392309 & 1.929544 & 2.50372 & 2.74615 & 2.61037 & 2.19409 & 2.503716 & 2.64497 & 8.1028 & 191.063 & 8.102830 \\
\hline Objek 12 & 11.14136 & 11.45056 & 9.83558 & 9.28842 & 12.3306 & 12.7694 & 12.43124 & 8.204774 & 16.56 & 167.952 & 16.560500 \\
\hline
\end{tabular}

Langkah berikutnya adalah melakukan proses yang sama dengan langkah pada nomor 3. Jarak dari hasil perhitungan akan dilakukan perbandingan dan akan dipilih jarak minimal antara data dengan pusat cluster, jarak ini menunjukkan bahwa data tersebut berada dalam kelompok yang sama dengan pusat cluster yang terdekat. 
Tabel 8. Hasil Pengelompokan pada iterasi ke -2

G2
\begin{tabular}{|c|c|c|}
\hline No & C1 & C 2 \\
\hline 1 & 1 & 0 \\
\hline 2 & 1 & 0 \\
\hline 3 & 0 & 1 \\
\hline 4 & 0 & 1 \\
\hline 5 & 1 & 0 \\
\hline 6 & 0 & 1 \\
\hline 7 & 0 & 1 \\
\hline 8 & 1 & 0 \\
\hline 9 & 1 & 0 \\
\hline 10 & 1 & 0 \\
\hline 11 & 1 & 0 \\
\hline 12 & 1 & 0 \\
\hline
\end{tabular}

Karena G2 = G1 memiliki anggota yang sama maka tidak perlu dilakukan iterasi atau perulangan lagi. Hasil pengklasteran telah mencapai stabil dan konvergen.

\subsubsection{Pengujian}

Berangkat dari tujuan penelitian ini, maka dilakukan pengujian terhadap metode yang digunakan untuk meningkatkan akurasi jumlah bibit bandeng yang kenali pada citra. Jumlah citra diuji sebanyak 30 citra, dimana pada masing-masing citra terdapat jumlah bibit bandeng bervariasi yaitu 20,30 dan 40 ekor. menggunakan 3 wadah yang sama dan setiap wadah dilakukan pengambilan gambar sebanyak 10 citra.

\section{- Pengujian ke -1}

Pengujian ini menggunakan data sebanyak 10 citra, dimana pada masing-masing citra terdapat 20 ekor bibit bandeng berdasarkan penghitungan secara manual. Dari pengujian tersebut didapatkan hasil sebagai berikut :

Tabel 9. Hasil Pengujian ke 1

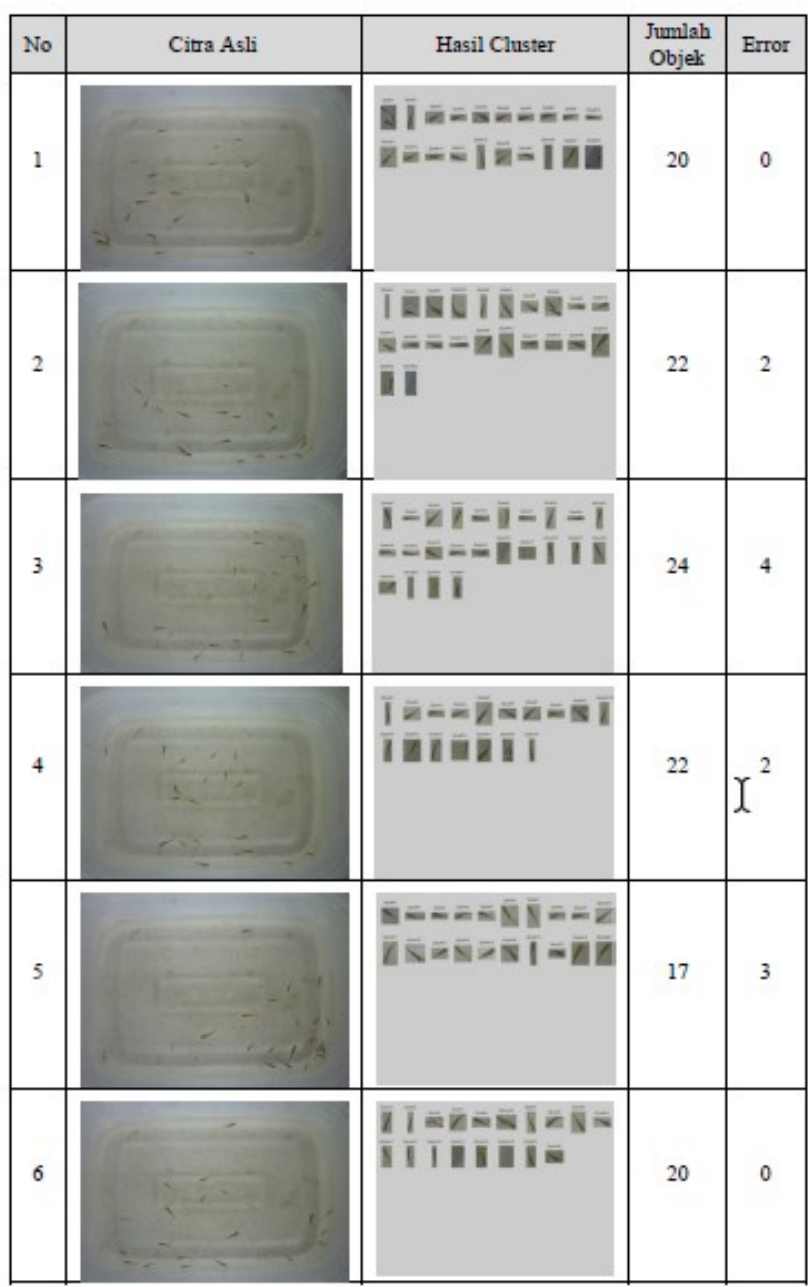

Ket :

Citra Asli : merupakan citra yang dihasilkan oleh kamera Cluster : Hasil pengklasteran dengan metode K-Means Jumlah Objek : Jumlah Objek yang berhasil dikenali oleh kmeans

Berdasarkan hasil pengklasteran citra pada pengujian ke-1, didapatkan jumlah bibit bandeng seperti pada tabel 10 .

Tabel 10 Jumlah Bibit Bandeng

\begin{tabular}{|c|c|c|c|}
\hline \multirow{2}{*}{ No } & \multicolumn{2}{|c|}{ Objek } & Bibit bandeng yang \\
\cline { 2 - 4 } & Bibit bandeng & Bukan bibit bandeng & \\
\hline 1 & 18 & 2 & 2 \\
\hline 2 & 20 & 2 & - \\
\hline 3 & 20 & 4 & - \\
\hline 4 & 18 & 4 & 2 \\
\hline 5 & 17 & - & 3 \\
\hline 6 & 20 & - & - \\
\hline 7 & 16 & 2 & 4 \\
\hline 8 & 17 & 1 & 3 \\
\hline 9 & 17 & - & 3 \\
\hline 10 & 18 & - & 2 \\
\hline
\end{tabular}

Dari tabel 10. di atas, didapatkan bahwa dari 10 citra yang dilakukan pengujian menunjukan hasil pengklasteran jumlah 
objek yang dikenali bervariasi dan masih terdapat objek bibit bandeng yang tidak dapat dikenali.

Pada penelitian ini akan menggunakan confusion matrix untuk mengevaluasi hasil pengklasteran untuk mendapatlkan jumlah yang kenali sebagai objek. Objek dalam penelitian ini adalah bibit bandeng dan bukan bibit bandeng .

Untuk mengukur tingkat akurasi dan error rate dilakukan dengan persamaan sebagai berikut :

$$
\begin{aligned}
& \text { accuracy }=\frac{T P+T N}{T P+F N+F P+T N} \times 100 \\
& \text { error }=\frac{T N+F P+F N}{T P+T N+F P+F N} \times 100
\end{aligned}
$$

Dimana :

TP : Bibit bandeng diprediksi bibit bandeng

TN : Bibit bandeng diprediksi bukan bibit bandeng

FP : Bukan bibit bandeng diprediksi bibit bandeng

FN : Bukan bibit bandeng diprediksi bukan bibit bandeng

Dari percobaan 1 didapatkan hasil akurasi sebesar 91.01\% dan error $8.99 \%$ dengan jumlah citra uji sebanyak 10 dan masingmasing citra terdapat 20 objek bibit bandeng. Hasil pengujian dapat dilihat pada tabel 11

\begin{tabular}{|c|c|c|c|c|c|c|c|}
\hline \multirow{2}{*}{ No } & \multirow{2}{*}{ Aktual } & \multicolumn{4}{|c|}{ Prediksi } & \multirow{2}{*}{$\begin{array}{c}\text { Akurasi } \\
(\%)\end{array}$} & \multirow{2}{*}{$\begin{array}{c}\text { Error } \\
(\%)\end{array}$} \\
\hline & & TP & $\mathrm{TN}$ & FP & $\mathrm{FN}$ & & \\
\hline 1 & 20 & 18 & 2 & 2 & 0 & 90.91 & 9.09 \\
\hline 2 & 20 & 20 & 2 & 0 & 0 & 100 & 0 \\
\hline 3 & 20 & 20 & 4 & 0 & 0 & 100 & 0 \\
\hline 4 & 20 & 18 & 4 & 2 & 0 & 91.67 & 8.33 \\
\hline 5 & 20 & 17 & 0 & 3 & 0 & 85 & 15 \\
\hline 6 & 20 & 20 & 0 & 0 & 0 & 100 & 0 \\
\hline 7 & 20 & 16 & 2 & 4 & 0 & 81.82 & 18.18 \\
\hline 8 & 20 & 17 & 1 & 3 & 0 & 85.71 & 14.29 \\
\hline 9 & 20 & 17 & 0 & 3 & 0 & 85 & 15 \\
\hline 10 & 20 & 18 & 0 & 2 & 0 & 90 & 10 \\
\hline \multicolumn{6}{|c|}{ Hasil Akurasi } & 91.01 & 8.99 \\
\hline
\end{tabular}

Tabel 11. Hasil Evaluasi Percobaan 1

\begin{tabular}{|c|c|c|c|c|c|c|c|}
\hline \multirow{2}{*}{ No } & \multirow{2}{*}{ Aktual } & \multicolumn{4}{|c|}{ Prediksi } & \multirow{2}{*}{$\begin{array}{c}\text { Akurasi } \\
(\%)\end{array}$} & \multirow{2}{*}{$\begin{array}{c}\text { Error } \\
(\%)\end{array}$} \\
\hline & & TP & TN & FP & FN & & \\
\hline 1 & 30 & 29 & o & 1 & o & 96.67 & 3.33 \\
\hline 2 & 30 & 28 & o & 2 & o & 93.33 & 6.67 \\
\hline 3 & 30 & 22 & $\mathrm{O}$ & 8 & $\mathrm{O}$ & 73.33 & 26.67 \\
\hline 4 & 30 & 25 & 0 & 5 & 0 & 83.33 & 16.67 \\
\hline 5 & 30 & 28 & $\mathrm{o}$ & 2 & o & 93.33 & 6.67 \\
\hline 6 & 30 & 25 & $\mathrm{o}$ & 5 & $\mathrm{o}$ & 83.33 & 16.67 \\
\hline 7 & 30 & 25 & o & 5 & o & 83.33 & 16.67 \\
\hline 8 & 30 & 26 & 0 & 4 & $\mathrm{o}$ & 86.67 & 13.33 \\
\hline 9 & 30 & 27 & o & 3 & o & 90 & 10 \\
\hline 10 & 30 & 24 & o & 6 & o & so & 20 \\
\hline
\end{tabular}

Tabel 13. Hasil Evaluasi Percobaan 3

Dari hasil percobaan 1,2 dan 3 didapatkan rata-rata akurasi sebesar $92.70 \%$ dan error $\mathbf{7 . 3 0} \%$.

\section{KESIMPULAN}

Dari hasil pengujian dapat dilihat bahwa dengan melakukan perbaikan pada tahapan preprocessing dengan menerapkan transformasi color ke Hue Saturation Value (HSV) dan Morfologi pada citra bibit bandeng sangat berpengaruh terhadap hasil pengklasteran menggunakan metode K-Means. Dengan menerapkan transformasi warna dari RGB ke HSV dan melakukan operasi morfologi terhadap citra S, V dan Grayscale terbukti dapat mempertajam citra objek bibit bandeng yang berada di dasar wadah atau objek bibit bandeng yang blur (kabur) dan dikenali pada saat dilakukan pengklasteran sehingga didapatkan hasil perhitungan yang lebih akurat. Berdasarkan hasil pengujian pada citra dengan jumlah objek bibit bandeng 20, 30 dan 40 didapatkan hasil rata-rata akurasi sebesar $92.70 \%$ dan tingkat error $7.30 \%$ dengan jumlah citra uji sebanyak 30 citra.

\section{DAFTAR PUSTAKA}

[1] Ruly Sutrisno Sinukun, dkk. "Identifikasi Jumlah Citra Nener Menggunakan Metode Blob”, Prosiding Seminar Nasional Aplikasi Sains \& Teknologi (SNAST) 2014 ISSN: 1979-911X Yogyakarta, 15 November 2014

[2] Munawir, dkk. "Identifikasi Otomatis Spermatozoa Sapi Menggunakan Support Vector Machine” AVA Journal of Electrical and Electronics Engineering Volume 12, Number 1, April 2014

[3] Sandi Desmanto, dkk "Penerapan Algoritma KMeans Clustering Untuk Pengelompokkan Citra Digital Dengan Ekstraksi Fitur Warna RGB”, STMIK GI MDP, Jalan Rajawali No.14 Palembang

[4] Silvi Agustina dkk," Clustering Kualitas Beras Berdasarkan Ciri Fisik Menggunakan Metode KMeans”, Program Studi Ilmu Komputer, Program Teknologi Informasi dan Ilmu Komputer Universitas Brawijaya Malang Jalan Veteran Malang 65145, Indonesia

[5] M Hafidh Fauzi, Prof.Ir.Handayani Tjandrasa, M.Sc., Ph.D 2, "Implementasi Thresholding Citra Menggunakan Algoritma Hybrid Optimal Estimation", $\quad$ http://digilib.its.ac.id/public/ITSUndergraduate-12935-Paper.pdf tanggal akses 11-102016

[6] Mauridi Hery P, Arif Muntasa,“Konsep pengolahan citra digital dan ekstraksi fitur”, Graha Ilmu, Indonesia 2010

[7] Moeslund, Thomas B. "Introduction to video and image processing: Building real systems and applications”. Springer Science \& Business Media, 2012.

[8] Arum tri Iswari, "Implementasi Algoritma Wavelet Haar untuk Menghilangkan Noise pada Citra Digital” Seminar Nasional dan Expo Teknik Elektro 2011 ISSN : 2088-9984 